\title{
求む社会起業家
}

\section{Wanted: social entrepreneurs}

\section{Nature Vol.434(941)/21 April 2005}

研究者から転じた起業家のおかげで、顧みられることのなかった希少疾病の ための新薬研究開発事業が息を吹き返している。研究者、経営者や資金提供 者は、このような事業に専門知識を提供し、あるいは独自に起業すべきである。

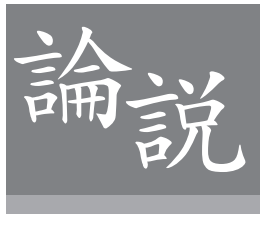

オープンソースの総合百科事典ウィキペディアには、カラ・ アザール (内臟リーシュマニア症) について記述するペー ジがない。でも誰も気に留めないだろう。そもそも開発途 上国で大勢の人々がかかり、骨と皮だけのようになった患 者の腹部が、肥大した肝臟と脾臓のために大きく膨れるよ うな病気だからだ。その薬は、治療単位当たりで最高 200 米ドル（約 22,000 円）もするため、治療を受けないままの 患者が多く、毎年、約 20 万人の死者が出ている。新薬開 発を目指す研究開発の流机の中では、約 8,000 種類の希少 疾病よりもシリコン豊胸手術や勃起障害のためのピルの研 究が熱心に行われている。希少疾病のひとつひとつの患者 数はせいぜい 2,000 人ほどだが、希少疾病といわれるもの すべてを合わせるとその患者数は数百万人にものぼる。

このような状況の根本原因は、希少疾病の市場が小さす ぎて、大手製薬会社が興味を示さないことにある。大手製 薬会社は連携して希少疾病対策に取り組んではいるが、株 主に対する責任も果たさなければならないのだ。研究段階 から製品化にまでいたるルートがあるわけだが、その各段 階にかかわる人々がこの現在の均衡状態を是正するために できることはあるだろうか。

4月 12〜15日にフランスのリヨンで開催された BioVision, World Life Sciences Forum において、Nature の共催に よる希少疾病に関する円卓会議が行われた。会議では、こ れらの疾病に真剣に対応するためには、みんながどれほど の力を合わせて取り組まなければならないかが明らかにな り、重苦しい空気に包まれた。ただ、その一方で、新たな 知見や問題打開につながる可能性のある道が示され、参加
者はある程度勇気づけられた。

この会議は、ポリオワクチンが承認されてから 50 年目を 迎えたことを記念して開催された。今や、ポリオは根絶寸 前の状態にある。ここに至るまでの状況は、ポリオの重要 な基礎研究に対して確かな支援を行ったマーチ・オブ・ダ イムス、そして 5 億ドル（約 550 億円）以上の資金を集め、 ボランティアを提供することでポリオワクチンを医療現場に 届けたロータリー財団の協力抜きには語ることはできない。 これらの団体は、重大なボトルネックに取り組んで、勝利 を収めた。その結果、今この記事を読んでいる人のほとん ぞは、わずか数十年前はポリオがすべての子供の親に恐れ られた病気だったとは気づかなくなるだろう。

ニューリーダーたち

新世代の「社会起業家」は、顧みられることのない希少疾 病に取り組むために、創意に富んだ方法を試している。た とえば、Victoria Hale は、非営利の製薬会社 Institute for OneWorld Health を米国サンフランシスコで設立したが、 彼女が踏み出したこの小さな一歩が人類にとっては大きな 飛躍となるかもしれない。彼女は、安全で効果的な力ラ・ アザール治療薬を治療単位当たり 10 ドル（約 1,100 円） で提供することにつながる可能性のある臨床試験結果をリ ヨンでの円卓会議で発表した。

Hale は、新薬開発をゼロから始めるのではなく、大学や 企業を訪礼て、別の病気に処方された薬剤や途中で開発作 業が中止された薬剤候補として引き出しに眠っているもの を探し歩いた。そして、住血吸虫症やシャーガス病のよう 
な病気の薬剤候補の開示を企業に強く働きかけ、その臨床 開発のために慈善基金を設立した。

この 10 ドルのカラ・アザール治療薬とは、パロモマイシ ンという 1950 年代から存在している特許切れの抗生物質 のことだ。Haleの会社は、ビル\&メリンダ・ゲイツ財団か ら資金援助を受けて、誰も手がけようとしなかった多額の 費用を伴う臨床開発と臨床試験を実施して、カラ・アザー ル治療薬としてのパロモマイシンの試験と販売を目指した。 薬剤の供給は、インドのジェネリック医薬品メーカーの助け を借りて実施されることになっている。

これと似た方法を実施しているのが国境なき医師団が創 設した Drugs for Neglected Diseases Initiative（スイス・ ジュネーブ)で、まだ数多くあるそのほかの顧みられない希 少疾病に取り組んでいる。このような組織は、既存薬㶡の 試験や配合改良に加えて、業界からの資金提供が得られず に研究室に放置されているリード化合物に活動の照準を合 わせることで、研究と臨床開発との大きなギャップを埋め ている。

開発段階におけるもう1つの重大なボトルネックは、動 物モデルや培養細胞を使った前臨床研究だ。ゲノミクスに よって、マラリアや結核のような主要な疾患だけでなく、 約 1,200 種類の希少疾病の分子的基盤が明らかにされ、新 たな薬剤標的分子が判明した。これにより、数多くの希少 疾病に対する治療効果が認められる可能性のある薬が初め て明らかになった。たと光ば、もし特定の疾病の分子的基 盤がインターロイキンAの発現と関係していれば、既存の インターロイキン $\mathrm{A}$ 阻害剤が治療薬となるかもしれない。 しかし、新たに判明した大量の薬剤標的を調べるために学 術研究者が必要とする数多くの薬剤類似物質は、企業だけ が持っている。

そこで遺伝子治療の専門家であるフランスの社会起業家 Alain Fischer は、各企業を説得して、企業が保持してい るが開発の行われていない大量の関連薬剤を研究者が利用 できるようにしょうと努力している。最近創設された European Rare Disease Therapeutic Initiative は、希少疾病の 治療に有望な分子を販売することについて企業に優先権を 与えている。もし、その企業が優先権を行使しなければ、 研究者は、別の企業や資金提供者に持ち込んで、臨床現場 への供給を目指すことができる。

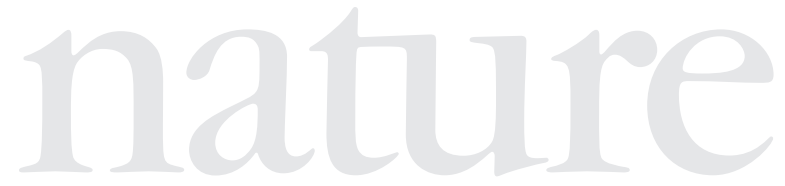

\section{粘り強く変化を待つ}

難点は、これらすべての組織が比較的小規模なことだ。こ のため、資金提供を受けられるかどうかが重大問題となる。 しかし Hale は強気だ。研究者、医師と社会起業家が意識 を高めて、それぞれの活動の正当性を主張すれば資金は得 られる、と彼女は言う。ロータリー財団のポリ才撲滅キャ ンペーンの先頭に立っている Robert Scott も同じ意見で、 政府、企業や研究機関の考方方は日々変化することを指摘 する。今日は否定的な対応を示した担当者が、明日になる と肯定的な対応に変わる可能性があるというのだ。粘り強 く運動を続ければ、報われるのである。

皮肉なことに、企業よりも大学が持つ権利の方が、そ れを取得して関係する分子を得るのは難しいという現実 がある。大学の技術担当部署は、積極的に特許を取得し、 収入を得ることだけを考元、企業とのライセンス契約に 扔いて希少疾病に取り組む上で役立つ条項を入れない傾 向がある。研究者や各研究機関は、その研究や知的財産 を社会的目的に利用できるように支援する Centre for the Management of Intellectual Property in Health Research and Development、Biological Innovation for Open Society、Science Commons といった団体に積極的に登録 すべきである。

希少疾病の研究開発に関しては、驚くほど大きなスケー ルで「市場の失敗 (market failure)」が起こっている。そ れに、研究や医療にかかわる数多くの利害関係者の間では、 この問題のスケールの大きさに対する認識が慢性的に低 い。研究課題を定め、個人や公立私立団体の資金提供者に 話を聴いてもらえる立場にある人々が、人の心を動かす息 の長いリーダーシップを実践することが必要とされている。 研究者、元業界幹部、資金調達者やその他の人々は、Institute for OneWorld Health (http://www.oneworldhealth. org/how) やその他の社会起業家に対して、研究に協力し、 専門知識を提供するボランティアとして名乗り出ることがで きる。また OrphanXchange (http://www.orphanxchange. org) や米国立衛生研究所希少疾病室 (http://www. rarediseases.info.nih.gov) を通じてネットワークに加わる ことができる。そして、もちろんのことだが、ウィキペディ アに適切なページを執筆して、この課題を強調することも 可能だ。 